\title{
Imprisonment and the Right to Freedom of Movement
}

Robert C. Hughes

The Wharton School, University of Pennsylvania

Final manuscript. Please cite the published version in Chris W. Surprenant, ed., Rethinking Punishment in the Era of Mass Incarceration, Routledge 2018. https://www.routledge.com/Rethinking-Punishment-in-the-Era-of-MassIncarceration/Surprenant/p/book/9781138047792

In American politics, it is common for liberals (and not uncommon for conservatives) to advocate imprisoning fewer offenders. ${ }^{1}$ Advocates of penal reform have given many reasons to replace prison with alternative sentences for non-violent crimes, in particular: among them, that imprisonment of non-violent offenders is a poor use of public resources, compared either with alternative punishments or with non-punitive ways of preventing crime (King 2005; Stemen 2007); that the experience of prison, at least in the United States, often has the opposite of a rehabilitative effect (Dolovich 2009); and that there are racial disparities in the rates at which non-violent offenders receive sentences of imprisonment (Blumstein 1993). Though advocates of penal reform have given many reasons our government should not imprison non-violent offenders, they typically have not questioned government's general entitlement to impose sentences of imprisonment for a wide range of offenses. Most of the standard arguments for penal reform object to incarceration not in the abstract, but in the context of contingent facts about the availability of alternative sentences, the effects of incarceration, and the ways in which the criminal justice system responds unfairly to class and race.

By contrast, some political philosophers have questioned government's entitlement to impose sentences of imprisonment. These challenges have questioned the extent of government's entitlement to impose punishment of any form. Some argue, for instance, that punishment is only justified under specific 
social circumstances which may not obtain in societies like ours (Hanna 2009). Others argue that government has little or no legitimate authority to impose obligations that go beyond natural duties, and that government therefore cannot legitimately punish most mala prohibita (Nozick 1974; Simmons 1995). These broad challenges to government's authority to punish apply to all forms of punishment, not only to imprisonment.

I shall argue that government's use of imprisonment raises distinctive moral issues. Even if government has broad authority to make and to enforce law, government may not be entitled to use imprisonment as a punishment for all the criminal laws it is entitled to make. Indeed, there may be some serious crimes that it is wrong to punish with imprisonment, even if the conditions of imprisonment are humane and even if no adequate alternative punishments are available. The moral problem with imprisonment is not that it is more severe than alternatives. Imprisonment is scalable in severity. It can be long or brief, and it can be highly restrictive or only moderately so. A reasonable person could regard a fine of half his life savings as a more severe punishment than a one-year sentence to be served in Norway's Bastoy Prison. Prisoners on Bastoy Island all have jobs, but they can fish and play tennis in their spare time, they have the keys to their rooms, and they have "views of the ocean that are postcard-worthy." (Sutter 2012) Imprisonment is distinctive in the way that it affects human agency. Even the most lenient forms of imprisonment deprive prisoners of freedom of movement. The loss of freedom of movement makes entire categories of human activity unavailable in a way that a financial penalty, even a large one, does not. The effects of imprisonment on human agency thus differ in kind, not only in degree, from the effects of sanctions such as fines and mandatory community service. Thus, imprisonment requires special justification, over and above the justification of punishment.

The only morally acceptable rationales for incarceration as a punishment, I argue, are moral education and collective self-defense. Though retribution may 
justify punishment of some form, it cannot justify incarceration. Moral education justifies imprisonment only if there is evidence that imprisonment does, in fact, morally educate. If such evidence is not forthcoming, the only possible justification for imprisonment in law enforcement is as a form of collective defense against wrongful attacks. Government may be entitled to imprison people (with due process) to address crimes that attack the necessary conditions for citizens' effective exercise of agency. These include crimes that attack citizens' agency directly, such as crimes of violence. These also include crimes that threaten the very existence of the state (e.g. treason), since effective exercise of human agency requires at least a minimally effective government. But there is a wide range of criminal prohibitions that we are justified in having but that the government is not morally entitled to enforce via imprisonment. These include many laws against minor offenses, such as disorderly conduct, but they also include some laws against offenses that are quite serious. Notably, they include prohibitions on white collar crimes such as insider trading that make the market less fair or that do small harms to large numbers of people but that do not seriously undermine anyone's effectiveness as an agent. ${ }^{2}$

The core of my argument is that if we fully understand why it is wrong for private individuals to engage in kidnapping, we will see that the moral objection to kidnapping applies more widely. Imprisonment by the state is often (but not always) wrong in the same way as kidnapping. The account of the wrong of kidnapping I offer will build on some of the core claims of Kantian ethics. ${ }^{3}$ I make no apologies for relying on a popular but controversial theoretical framework. Others have defended this framework, and I will not attempt to motivate it here. Those who are unsympathetic to Kantian ethical theory likely will not find my argument congenial. Nonetheless, consequentialists may be pleasantly surprised by the conclusion that on the Kantian approach, empirical facts about the effects of imprisonment are relevant to its permissibility. 


\section{The Value of Freedom of Movement}

I shall begin by arguing that imprisonment interferes in a distinctive way with the exercise of rational agency. All penalties interfere with some of the things that the penalized person wants or could want. Fines, for instance, reduce people's ability to do things they want by reducing their financial resources. If imprisonment is distinctively problematic, the problem cannot be simply that imprisonment keeps people from doing some of the things they want. At the same time, it would be absurd to claim that imprisonment keeps people from exercising agency at all. Obviously, prisoners do things. Imprisonment of any form is problematic because it entirely deprives people of one of the central means of human agency.

Imprisonment takes many forms. Though many prisons are extremely unpleasant places, there are some prisons (like Bastoy) that people could reasonably find pleasant. Many prisons regulate inmates' activities tightly, but others do not. Indeed, people can count as prisoners even if authorities disclaim any right to regulate how prisoners spend their time. The only right all prisoners are denied is the right to leave the space to which they are confined. Not all limitations on freedom of movement are normally characterized as imprisonment. I shall use the term "imprisonment" to refer to involuntary confinement that physically separates people from the rest of society. The word "involuntary" here is crucial. People who voluntarily travel on ocean vessels or space ships are confined to spaces that are physically separated from the rest of society, but their voluntary, temporary confinement enhances their agency by helping them to go where they want. Some involuntary limitations on travel, such as house arrest and the use of ankle monitors, do not physically separate people from society. I leave open the question whether these restrictions on movement raise the same ethical concerns as imprisonment.

The loss of freedom of movement involved in imprisonment interferes with the exercise of agency in a distinctive way. Locomotion is a primary means of agency for human beings. It is required for any project that requires observing the 
world personally (i.e. not via others' reports) beyond the tiny corner of the world an individual can perceive at a given moment. It is also required for any project that involves physically altering the world by one's own efforts (i.e. not by directing others' efforts) beyond the tiny corner of the world one can reach without moving the whole of one's body. Perhaps most importantly, freedom of movement is a prerequisite for effective freedom of association, and thus for the ability to select and to pursue projects that require others' help. The problem here is not so much with compelled association - though that is a feature of many forms of imprisonment-but with the inability to meet in person with people of one's own choosing. Even if an imprisoned person has unlimited and unmonitored access to mail, telephone, and electronic communication, and even if visits are allowed without restriction, the prisoner cannot meet in person with anyone who is unable to make the trip, nor can the prisoner attend meetings of associations. Many human projects are either impossible or seriously hampered by the inability to meet in person with other participants.

Freedom of movement, then, is one of the basic, all-purpose means of human agency. All-purpose means of human agency are means without which major categories of human activity are foreclosed. Among the other all-purpose means of human agency are the ability to possess and to use physical objects, the ability to solicit the help of others, and the ability to draw on our own skills and talents. ${ }^{4}$ Though a person who has lost one of these all-purpose means of agency can still live and act, her agency is greatly impaired. Of course, the loss of a specific resource, such as a piece of property or a sum of money, can impair someone's agency. But the complete loss of access to one of the basic all-purpose means is an impairment of a different kind. Being imprisoned is less like being deprived of a specific sum of money and more like being prohibited from using money at all.

One might object that a loss of a specific resource-for instance, a large sum of money-might impair someone's agency more than the loss of freedom of 
movement. Admittedly, for some people, losing a large sum of money may interfere with their ability to achieve the ends they currently have more than losing freedom of movement would. Imagine a solitary miser who is uninterested in travel and whose chief pleasures are reading, writing, drawing, and contemplating her own wealth. For her to be incarcerated at a prison with a good library and an adequate supply of paper and pencils would frustrate her present desires less than would the loss of a large part of her financial resources. If she is confined more than briefly, however, she will be greatly limited in her ability to revise her ends. ${ }^{5}$ She cannot pursue any projects that require any form of travel, and she cannot pursue projects that require forms of association that her confinement prevents. By contrast, if she loses a large sum of money, her present desires may be frustrated, but the whole category of projects that involve money does not become off-limits to her. Imprisonment thus interferes with prisoners' effective agency in a serious way, a way that differs in kind from merely preventing people from getting things that they want.

\section{The Duty to Respect Agency and the Wrong of Kidnapping}

So imprisonment affects agency in distinctive ways. But surely sometimes we may permissibly restrict people's agency. The question is when. To determine when it is morally acceptable for a government to restrict people's agency, I will first address a different question: why is kidnapping typically wrong? I will offer a Kantian answer to this question. If this Kantian account of the wrong of kidnapping is sound, it implies that there is a more extensive duty to respect freedom of movement.

My Kantian account of the wrong of kidnapping will build on Barbara Herman's Kantian account of the duty to refrain from intentional killing (Herman 1989). Consider first cases in which one person kills another merely to satisfy a

desire, such as a desire to get an inheritance sooner. Such killings are obviously wrong. What explains the wrongness of such killings? According to the Kantian 
ethical framework, killing someone merely to satisfy a desire is permissible only if people could rationally endorse the universal acceptance of ethical norms that permitted such an action. Whether people can rationally endorse universal acceptance of norms depends on whether endorsing universal acceptance of these norms is consistent with the commitments that reason itself demands. (It is not relevant whether the acceptance of these norms would satisfy people's actual desires and preferences.) If I endorsed ethical norms that permitted people to kill whenever they take killing to advance their own interests, then I might thereby endorse someone killing me, since someone could take it to be in their interest to kill me. As a rational agent, if I will anything at all, I am rationally committed to my continued existence as a rational agent. So if I will anything at all, I cannot rationally endorse ethical norms that permit people to destroy my agency, that is, to kill me, whenever doing so would help them to satisfy a mere desire.

A parallel argument explains why it is wrong to kidnap someone merely to satisfy a desire. It is obviously wrong to kidnap someone to obtain a ransom or to prevent the victim from closing a deal with a business competitor. What makes such kidnappings wrong, on the Kantian account? These acts are permissible only if one could coherently endorse universal norms that authorized such actions. If I endorsed ethical norms that permitted people to kidnap whenever they took kidnapping to advance their own interests, then I might thereby endorse someone kidnapping me. Can I do so coherently? Kidnapping is unlike killing in that it does not destroy the agency of the victim; it need not involve even a threat of bodily harm. So a commitment to my continued existence as a rational agent is at least superficially consistent with endorsing others kidnapping me. To explain why kidnapping is wrong, on this Kantian framework, it is necessary to explain why people are rationally committed to having freedom of movement.

Human beings are rationally and morally committed to preserving their freedom of movement because people are morally required to prepare to fulfill future moral requirements. These include universal moral duties (such as the duty 
to benefit people in need and the duty to preserve oneself) as well the obligations people have acquired (such as promissory obligations and the obligations parents have to care for their children). Some things we need to satisfy moral requirements are predictable. To preserve oneself, one needs food; to care for one's children, one needs food for them. Other needs are unpredictable. It is not always possible to predict what one will have to do to get food for oneself and one's children. It is often impossible to predict what one will have to do to be a good parent, a good friend, or a good citizen.

To be prepared to fulfill unpredictable future moral requirements, we need resources that can be used for many possible purposes. We need broadlyapplicable skills and talents. ${ }^{6}$ We need the opportunity to ask others' help. ${ }^{7}$ We need the opportunity to obtain property-i.e., physical resources that we are free to use without others' interference. Because so many possible activities, tasks, and projects require the ability to move from one place to another, we need freedom of movement. Since rationality and morality require us to preserve our access to all-purpose means, every human being is rationally and morally committed to preserving their freedom of movement.

This does not entail that one is morally required to maximize one's available means. It is not clear what would even count as maximizing one's available means, since increasing the availability of one means almost always involves missing out on another. More time studying language means less time studying mathematics; pursuing greater financial resources through more hours of paid labor involves giving up leisure time available for discretionary purposes. Rather, rationality and morality prohibit entirely giving up one of the all-purpose means of action when there is no compelling reason to do so. One can rationally and morally choose not to take the highest-paying job, but one cannot rationally or morally vow never to accept income or to own property. One can rationally commit never to go to a particular place, but one cannot rationally abandon freedom of movement in general. One should not entirely give up an all-purpose 
means of action because one needs these means available to be able to respond flexibly to unpredictable future duties and obligations. Because the all-purpose means of action are prerequisites for whole categories of human action, their availability contributes more to one's ability to fulfill unpredictable future duties than any specific resource. Of course, the loss of a specific resource could interfere with one's fulfillment of a known obligation. Losing a sum of money earmarked for a particular purpose might prevent one from fulfilling a promise, for instance. But the loss of a specific sum of money does not make whole categories of human action impossible, so a financial loss interferes less than does confinement with one's ability to fulfill the unpredicted and unpredictable demands of morality.

The rational and moral duty to preserve one's all-purpose means explains the wrongness of most instances of kidnapping. I cannot rationally endorse someone else kidnapping me to fulfill a desire I have no duty to help fulfill. I thus cannot endorse ethical norms that permit people to kidnap others whenever doing so advances their interests. Thus, on the Kantian view of morality, kidnapping others to advance one's interests is wrong.

\section{From Kidnapping to Imprisonment}

Of course, there are morally salient differences between kidnapping by private citizens and the imprisonment of accused and convicted criminals by the state. Nonetheless, the Kantian argument against kidnapping extends to some (but not all) uses of imprisonment by the state. This section will explain three ways in which the reasoning of the argument against kidnapping can be extended. First, the argument against kidnapping applies to agents of the state. One might think that the principles of just or legitimate state action differ from the ethical principles that apply to individual action. The state is entitled to do many things that individuals are not entitled to do. Why not think that the ethical principles regulating just imprisonment by the state differ from the ethical principles regarding kidnapping by private citizens, just as the ethical principles regulating 
just seizures of property by the state differ from the ethical principles regarding stealing?

If the above arguments for duties to respect individual agency are correct, however, these duties apply to state actors. Nothing about these arguments limits their application to the action of private individuals. For the same reason it is wrong for an individual to kill in order to satisfy her own her own mere desire, it is wrong for a state actor to kill as a means of satisfying the mere desires of the many. Someone who endorses ethical norms authorizing agents of the state to kill as a means of satisfying public preferences might thereby endorse the destruction of her own agency. Likewise, it is wrong for the state to incarcerate innocent citizens as a means of satisfying public preferences. Someone who endorses ethical norms authorizing agents of the state to imprison citizens for the sake of satisfying public preferences might thereby endorse her own incarceration.

Though the primary argument against kidnapping for the sake of preference-satisfaction applies equally to private individuals and to the state, there are additional constraints on uses of imprisonment by private individuals. For example, the state can provide a form of due process that private citizens cannot. So it may turn out that there are some ends (other than preferencesatisfaction) that justify incarceration by the state but that do not justify private citizens in using force against each other.

This raises the question whether the argument against kidnapping can be extended in a second way. Does the argument against confining people to satisfy private desires or public preferences also prohibit confining people to achieve better ends than mere preference-satisfaction? For the moment, consider only confinement of people not convicted or suspected of crimes. The Kantian explanation for the wrongness of kidnapping implies that it is morally acceptable to confine innocent people only if those people could rationally and morally endorse their own confinement. People can rationally and morally endorse their own confinement only if doing so would be consistent with their other duties. 
Since people have a duty to prepare to fulfill unpredictable future duties, and because freedom of movement is one of the central, all-purpose means of human action, people have a pro tanto duty not to endorse their own confinement. Normally, the fact that an act would bring about a good result does not, by itself, justify violating a pro tanto moral duty. Only a weightier or higher-priority moral duty can justify violating a pro tanto moral duty. It is thus wrong to imprison innocent people unless these people have an important moral duty that their confinement would help to fulfill.

Quarantine of people with highly infectious and dangerous diseases is justified, on this account. People have a moral duty to avoid endangering others' lives. If one has a highly infectious, dangerous disease, going into quarantine would help to fulfill this duty. By contrast, it is wrong knowingly to incarcerate an innocent person as a scapegoat in order to calm a restive population. Calming a restive population is a good thing, but individuals do not have a moral duty to submit to incarceration in order to calm a restive population. The duty to preserve one's own effective agency and to prepare to fulfill future duties has more weight. On a Kantian picture of morality, a duty to address a grave threat to someone's agency (e.g. a threat to life) is the only duty that can outweigh the duty to preserve the effectiveness of one's own agency. Thus, imprisoning the innocent is justified only if it addresses a grave threat to someone's agency.

The third extension of the argument against kidnapping concerns respect for the agency of the guilty. Thus far, I have argued that it is wrong to confine innocent people as a means to any end other than protecting people's agency. But when government imprisons convicts, thereby depriving them of one of the central means of human agency, typically it imprisons people who are not innocent. When is it permissible to undermine the effective agency of someone who has done a legal or moral wrong in the past?

It is intuitively obvious that criminals retain some of their rightsincluding, at least, their right not to be kidnapped by private persons for reasons 
unrelated to their crimes (Quinn 1985). One might worry that the earlier Kantian reasoning is unable to explain this. According to that line of reasoning, I cannot endorse ethical norms that condone interference with the agency of the innocent, since I might thereby endorse interference with my own agency. Since my actions are in my own control, however, I can guarantee that I will always be an innocent person. If I endorse ethical norms that permit interference with the agency of the guilty, I would not thereby endorse interference with my own agency.

But it would be hubris for me to think I can guarantee that I will never, at any point in the future, commit a wrong. Human beings are flawed. Only a conceited, deluded person could think that he could guarantee he will never do anything morally wrong. It would also be hubris to think one will never break the law. Perhaps someone could know that because of way her character is constituted, there are specific crimes or types of wrongdoing that she is extremely unlikely ever to commit. But this knowledge would not license endorsing ethical norms that permit undermining the agency of people who commit those specific crimes or wrongs. The rational acceptability of ethical norms does not depend on knowledge of the peculiarities of one's own character and situation. A sound system of ethical norms must be acceptable to all flawed human beings, not only to those who have certain flaws and lack others.

As flawed rational agents, we are rationally committed to remaining effective agents and to being able to carry out our moral duties and obligations, even after having done a wrong. An agent's rational commitment to the preservation of the effectiveness of her own agency does not depend on moral desert. All human rational agents are committed to preserving their freedom of movement, since any of us could, in the future, have duties that can only be fulfilled by moving freely. In thinking about what ethical norms are acceptable, then, we must consider the possibility that we will ourselves do wrong, and that we remain committed to the importance of our effective agency if we do. 
Properly understood, then, the Kantian argument against kidnapping implies that the mere fact that someone has committed a moral or legal wrong in the past has no bearing on the permissibility of confining that person. There is a separate question whether one may confine a person or threaten to confine a person to prevent that person from committing a wrong or a legal offense. This is a special case of the general question when defensive force is justified. It is easy to see why it is permissible to use force that stops a wrongful attack without doing anything to undermine the attacker's future agency (e.g. blocking a punch). It is harder to see why it is permissible to use defensive force that has long-term effects on an attacker's agency (e.g. killing or injuring an attacker in self-defense). Appealing to a distinction between intended and merely foreseen harms will not do. When someone kills in self-defense, the death of the attacker is usually the means of stopping the attack; it is not merely a foreseen, unintended side-effect of stopping the attack.

Here is one possible explanation why defensive force is permissible even if it undermines the agency of the attacker in a way that goes beyond blocking the attack. When defensive force is proportional to the gravity of a wrongful attackwhen impairment of the attacker's agency is no greater than the impairment the attack would have done to the victim's agency had it succeeded-defensive force shifts the costs of a moral failure from the victim to the wrongdoer. Flawed rational agents who know that they could become attackers, but who also know that they could be victims, have no objection to ethical norms that permit the costs of their own errors to be shifted onto them. Though everyone is rationally committed to valuing his own agency, no one is rationally or morally entitled to value his own agency more highly than the agency of others. So attackers and potential attackers have no objection to defensive force that is proportional to the gravity of a wrongful attack. Defensive force that undermines the attacker's agency is only justified in response to an attack that could wrongly interfere with someone's agency, however. If an action is wrongful in some other way, defensive 
force cannot be justified as shifting the harm to agency from the would-be victim to the attacker. For example, it is wrong to use force to stop actions that are disrespectful but not injurious.

\section{Justifying Imprisonment}

I have argued that if we understand the wrong of kidnapping correctly, we will see that there is a broader moral duty to respect agency which prohibits confining people against their will in many circumstances. The only exceptions to this prohibition on involuntary confinement involve the protection of agency. It may be acceptable to confine innocent people against their will to prevent serious harm to someone's agency (e.g., death from disease). It may be acceptable to use or to threaten confinement as a means of defense against present or future wrongdoing - but only if the wrongdoing would threaten either people's agency itself or their effective access to one of the all-purpose means of agency. This section will defend some moral limits on the use of incarceration that follow from these principles. To do so, it will examine the extent to which any of three most influential justifications of punishment-retribution, moral education, and deterrence-can overcome the moral presumption against involuntary confinement.

The ethical principles concerning restriction of agency do not admit retribution as a justification of imprisonment. As flawed rational agents, we are all rationally committed to the preservation of our agency, and this commitment is not conditional on any assessment of the merits of our past actions. We are also rationally committed to the availability of all-purpose means, such as freedom of movement, to help us satisfy unpredictable future moral duties and obligations. We could not rationally consent to ethical norms that allowed people (including state actors) to undermine or to threaten other people's agency as a backwardlooking remedy for a past wrong. Nor could we rationally consent to ethical norms that allowed people to deprive others of all-purpose means of agency as a 
backward-looking remedy. Only the hope of protecting or promoting someone's present or future agency or their access to all-purpose means can justify imprisonment in any form. This does not imply that there is anything wrong with retributive theories of punishment. It only implies that retributive theories of punishment cannot support incarceration as a punishment.

One might try to argue that punishing people for their past wrongs is a way of respecting their agency. Kant's own theory of punishment could be interpreted as taking this position. We respect a thief's misguided exercise of agency by imposing on the thief the form of insecurity that the thief's maxim of action would have imposed on everyone (Kant 1796: 474, Ak. 6:333). But it is not plausible to think both that we have a duty to respect criminals' mistaken exercises of agency by imposing penalties and that this duty outweighs our duty not to prevent criminals from fulfilling future duties.

Moral education theories of punishment, by contrast, may provide broad support for the use of imprisonment as a punishment. Imprisonment may be morally permissible when its use enhances prisoners' effective rational agency overall, even though it undermines or threatens the conditions of rational agency temporarily. Assuming that citizens are morally required to refrain from doing all the things that criminal statutes prohibit, citizens who violate criminal statutes display a defect in their rational agency. Imprisonment as a punishment could enhance these citizens' rational agency if it helps them to understand the moral reasons to refrain from crime and to be motivated by these reasons in the future.

Punishment could contribute to moral learning in two ways. On communicative models of moral education through punishment, the fact of punishment itself expresses a message with moral content to the convicted criminal (Hampton 1984; McTaggart 1896; Morris 1981). ${ }^{8}$ It could communicate, for instance, that we collectively reject the conduct for which the convict is being punished. On a treatment of model of moral education, punishment is organized so that the experience of punishment contributes to moral learning. The 
experience of hard treatment could be intended to give convicts empathy for the suffering of their victims. Or convicts could be put in an environment that is designed to help develop habits of moral behavior.

Moral education theories have an important limitation as a justification for imprisonment. A moral education theory of punishment only justifies imprisonment if there is positive evidence that the form of imprisonment used or threatened actually does educate. To justify a limitation of agency that would ordinarily be wrong, it is not enough to speculate that this limitation could lead to an overall enhancement of the restricted person's agency. It is necessary to have empirical evidence that temporarily limiting a person's agency is likely to have an educational effect. In assessing the educational effects of imprisonment, one must keep in mind that punishment succeeds at moral education only if the person being punished comes to recognize the moral reasons to behave better. If all that a punished person learns is that a certain behavior leads to aversive consequences, moral education has not taken place, and the agency of the punished person has not been enhanced. So evidence that imprisonment improves convicts' behavior after release is not sufficient to show that prison is an effective form of moral education, since the improvement could be a result either of moral education or of specific deterrence.

If evidence that imprisonment morally educates is not forthcoming, the only justification of imprisonment as a punishment would be collective defense. The principle of justified defensive force permits acts that undermine someone's agency as a means of preventing that person from wrongfully undermining another person's agency. Justified defensive force is limited to actions that are necessary to prevent wrongful acts and proportional to the harm to agency that the would-be wrongdoer threatens. For the defensive principle to authorize imprisonment as punishment, the explanation how imprisonment contributes to the defense of agency would have to be indirect. Imprisonment as a punishment does not aim to prevent a convict from committing a specific wrong against a 
specific potential victim. One possible line of argument is that the threat of imprisonment serves to protect citizens generally against wrongful violence.

Warren Quinn's theory of punishment could be used to produce a justification along these lines for imprisonment of violent offenders (Quinn 1985). ${ }^{9}$ In many contexts, it is not possible to prevent wrongful violence by directly using force against the attacker, but it is possible to prevent wrongful violence by making a sincere and credible threat to harm the attacker in the future if the attack continues. If the attacker does not have a legitimate complaint against the immediate use of defensive violence, the attacker does not have a legitimate complaint against issuing a sincere threat of future harm that is no more serious than defensive harm that would be justifiable in the present moment. Threatening a term of imprisonment would be threatening a less serious harm than death or serious bodily injury, both of which are permissible defensive responses to attempted murder or mayhem. If it is not wrong for the legislature to make this threat credibly and sincerely to would-be violent criminals throughout the population, it is not wrong for government to carry out the threat against people who commit wrongful violence in defiance of the legislature's threat.

This account may be vulnerable to objections, either as an account of punishment in general or as an account of justified imprisonment. My aim here is not to defend Quinn's account, but to point to two limitations that result from the account's reliance on the defensive principle. First, imprisonment may only be used as a punishment for intentional violations of laws that are needed to protect either agency itself (e.g. protections of life and bodily integrity) or the availability of all-purpose means of agency (e.g. basic liberties, the opportunity to have property). These may include laws that are indirectly necessary to protect citizens' agency. Since some of the all-purpose means of agency, such as property, only exist in a civil condition, imprisonment may be used to enforce laws that are strictly necessary to the operation of a minimally functional state, such as tax laws and laws against bribery, election fraud, and treason. But it would be a mistake to 
that the state's ability to protect citizens' effective agency requires general compliance with every justified regulation the state issues. Rational agency can flourish despite widespread disobedience of laws that are inessential to its protection.

Collective defense accounts of punishment impose a further limitation on imprisonment in law enforcement: the use or threat of imprisonment to enforce a given law must be proportionate to the threat to agency that violations of this law pose. The threat to imprison people for serious crimes of violence would be proportionate to the threat that such crimes pose to individual victims' agency. Whether imprisonment may be used to enforce property laws is less straightforward. Theft undermines one of the victim's all-purpose means of agency, namely the opportunity to have property. One small theft, or one large theft from a well-off person, does not constitute a great enough interference with the victim's property for imprisonment to be a proportionate response. Widespread theft, however, would seriously threaten everyone's ability to control property. Perhaps it could even undermine a society's economic system in a way that threatens everyone's ability to sustain themselves. One might argue that because widespread theft, even widespread petty theft, would seriously threaten citizens' effective agency, the legislature is justified in sincerely threatening everyone with incarceration if they engage in theft.

Even if there is a sound argument for imprisonment as a punishment for theft, defense of citizens' agency cannot justify the use of imprisonment to enforce every justified criminal prohibition. Some justified criminal laws protect only an aspect of one of the all-purpose means of agency. Consider laws against simple trespass. Though widespread violation of laws against simple trespass would undermine an aspect of one of the all-purpose means of agency, the ability to have and to control property, it would not deprive people of effective property rights altogether. Since imprisonment deprives people of freedom of movement entirely, the threat of imprisonment is not a proportionate defensive response to 
the crime of simple trespass. Other justified criminal laws do not protect people's agency at all; they protect people's welfare. For example, laws against disorderly conduct are justified, but since many forms of disorderly conduct do not threaten anyone's agency—-they only interfere with people's welfare-laws against disorderly conduct should not be enforced using the threat of imprisonment.

Though many of the laws that should not be enforced via imprisonment concern minor crimes, some laws should not be enforced via imprisonment even though they concern serious forms of wrongdoing. Consider laws against insider trading. Though there is debate about whether insider trading is wrong, there are reasons to regard it as a form of fraud or deception that is seriously wrong. On the "traditional theory," insider trading by executives of the firm whose stock is traded violates a fiduciary duty to shareholders. United States v. O'Hagan, 521 U.S. 642, 651 (1997). Another theory holds that insider trading involves a misappropriation of information and thereby violates a duty of trust owed to the source of information. Id. at 652. Still a third theory holds that insider trading involves deception of the investors with whom one is trading. If one has an informational advantage to which one is not entitled, it is deceptive to use this advantage in trading; one should either disclose what one knows before trading or refrain from trading on the information (Strudler and Orts 1999; Strudler 2009). Though insider trading is arguably seriously wrong, and though it does real harm to investors who are not insiders, the harm is typically diffuse. Rarely, if ever, do individual victims suffer losses great enough that the victim is altogether deprived of the effective right to possess financial resources. The harm that widespread insider trading would do is unlikely to undermine the economic system in a way that threatens people's effective agency. Indeed, some have argued that the practice of insider trading can contribute to economic efficiency by spreading information about the appropriate valuation of securities (Ma and Sun 1998) or by providing an incentive for entrepreneurship (Manne 1966), though others doubt that insider trading promotes efficiency (Werhane 1989). So 
a collective defense theory of imprisonment cannot justify the threat of imprisonment as a punishment for insider trading. Insider trading may be a serious crime that deserves serious punishment, but moral desert alone cannot justify incarceration.

\section{Conclusion}

Many governments use imprisonment to enforce a wide variety of criminal laws, but government's entitlement to make criminal laws quite possibly exceeds its entitlement to use imprisonment as an enforcement mechanism. Imprisonment affects people's agency in distinctive ways that are difficult to justify. The only possible justifications for imprisonment in law enforcement are moral education and collective defense. Collective defense may justify the use of imprisonment to punish violent crimes and other crimes that attack people's ability to exercise agency effectively. It does not justify the use of imprisonment to enforce all justified criminal laws. Moral education theories of punishment may justify a broader use of imprisonment as punishment, but only if there is positive evidence (not mere speculation or hope) that imprisonment helps people to recognize the moral reasons to do what the law says. The question whether any actual system of incarceration has this effect I must leave to readers' judgment. ${ }^{10}$ 


\section{References}

Blumstein, A. (1993) "Racial Disproportionality of U.S. Prison Populations Revisited," University of Colorado Law Review 64 743-760.

Byrd, B.S. (1989) "Kant's Theory of Punishment: Deterrence in its Threat, Retribution in its Execution," Law and Philosophy 8 151-200.

Dagan, D. and Teles, S.M. (2012) "The Conservative War on Prisons," Washington Monthly Nov/Dec.

Dolovich, S. (2009) "Incarceration American-Style," Harvard Law and Policy Review 3 237-259.

Hampton, J. (1984) "The Moral Education Theory of Punishment," Philosophy \& Public Affairs 13 208-238.

Hanna, N. (2009) "Liberalism and the General Justifiability of Punishment," Philosophical Studies 145 325-349.

Herman, B. (1984) "Mutual Aid and Respect for Persons," Ethics 94 577602.

Herman, B. (1989) "Murder and Mayhem," The Monist 72 411-431.

Kant, I. (1785) Groundwork of the Metaphysics of Morals. Translated by M. J. Gregor, 1996, in Practical Philosophy, Cambridge, U.K.: Cambridge University Press.

Kant, I. (1797). The Doctrine of Right. Translated by M. J. Gregor, 1996, in Practical Philosophy, Cambridge, U.K.: Cambridge University Press.

King, R.S. et al. (2005). "Incarceration and Crime: A Complex Relationship." Sentencing Project. Available at $<$ http://www.sentencingproject.org/publications/incarceration-and-crime-acomplex-relationship/> [Accessed December 8, 2016].

Ma, Y. and Sun, H.L. (1998) "Where Should the Line Be Drawn on Insider Trading Ethics?" Journal of Business Ethics 17: 67-75.

Manne, H.G. (1966) "In Defense of Insider Trading." Harvard Business Review 44(6) 113-122. 
McTaggart, J.E. (1896) "Hegel's Theory of Punishment," International Journal of Ethics 6 479-502.

Morris, H. (1981) "A Paternalistic Theory of Punishment," American Philosophical Quarterly 18 263-271.

Nozick, R. (1974) Anarchy, State, and Utopia, New York: Basic Books.

Quinn, W. (1985) "The Right to Threaten and the Right to Punish," Philosophy \& Public Affairs 14 327-373.

Rawls, J. (2005) Political Liberalism, New York: Columbia University Press.

Simmons, A.J. (1995) On the Edge of Anarchy: Locke, Consent, and the Limits of Society, Princeton: Princeton University Press, 1995.

Stemen, D. (2007) "Reconsidering Incarceration: New Directions for Reducing Crime" Vera Institute of Justice. Available at $<$ https://www.vera.org/publications/reconsidering-incarceration-new-directionsfor-reducing-crime $>$ [Accessed December 8, 2016].

Strudler, A. (2009) "The Moral Problem in Insider Trading," in Brenkert, G.G. and Beauchamp, T.L. (eds.), Oxford Handbook of Business Ethics, Oxford: Oxford University Press.

Strudler, A. and Orts, E.W. (1999) "Moral Principle in the Law of Insider Trading," Texas Law Review 78(1999): 375-437

Sutter, J.D. (2012) "Welcome to the World's Nicest Prison," CNN, May 24, 2012 Available at http://www.cnn.com/2012/05/24/world/europe/norwayprison-bastoy-nicest/[Accessed December 10, 2016].

United States v. O'Hagan, 521 U.S. 642, 651 (1997).

Werhane, P. (1989) “The Ethics of Insider Trading," Journal of Business Ethics 11 841-845. 
1 For discussion of the penal reform movement on the right, see Dagan and Teles 2012.

2 I do not count laws against drug possession and trafficking as examples because there is controversy about whether criminal law should regulate recreational drugs at all.

3 Though I use a Kantian ethical framework, I will not attempt either to interpret or to defend Kant's opaque discussion of criminal punishment in the Doctrine of Right.

4 Barbara Herman identifies three central means of human agency: skills, things, and the help of others (Herman 1984: 585). I suggest here that movement, including free locomotion, should be added to this list.

5 In Rawlsian terms, loss of freedom limits a person's ability to revise and pursue a conception of the good. John Rawls added freedom of movement to his list of primary goods, aptly but without explanation, in Political Liberalism (Rawls 2005: 181).

6 This is why Kant believes that it is immoral to neglect the development of one's talents (Kant 1785: 74-75, Ak. 4:423).

7 This is why Kant believes that it is immoral to have a policy of never helping anyone (Kant 1785: 75, Ak. 4:423)

8 None of these theories is intended to justify imprisonment in particular. Jean Hampton explicitly states that her theory "rejects many forms of incarceration used today." (Hampton 1984: 228).

9 On Sharon Byrd's interpretation of Kant's cryptic remarks about punishment, Kant's own theory of punishment has a somewhat similar structure (Byrd 1989).

10 I am grateful to Barbara Herman, Herbert Morris, Stephen Munzer, Seana Valentine Shiffrin, Alan Strudler, and the members of the UCLA Ethics Writing Seminar, the UCLA Legal Theory Workshop, the Wharton LGST junior faculty workshop, an audience at IRV 2015, and the workshop on incarceration at the University of New Orleans for helpful comments on previous drafts. 